\title{
Boitempo: a recordação em Carlos Drummond de Andrade
}

\author{
Juliana Santos
}

Resumo: Este artigo apresenta uma leitura da obra Boitempo, de Carlos Drummond de Andrade, publicada em três volumes nos anos de 1968, 1973 e 1979. Considerada como testemunho biográfico do poeta, esta poesia é analisada principalmente sob a luz das obras Conceitos fundamentais da poética, de Emil Staiger, e Le sens de la mémoire, de Jean-Yves e Marc Tadié, como forma de destacar o trabalho com os cinco sentidos e o caráter lírico dessa produção fundamentada no sentimento da recordação.

Palavras-chave: Carlos Drummond de Andrade; Boitempo; memória.

\begin{abstract}
This article presents a reading of Boitempo, by Carlos Drummond de Andrade, published in three volumes in the years 1968, 1973 and 1979. Considered to be the poet's biographical testemonial, this poem is analyzed especially under the perspective of the works Conceitos fundamentais da poética, by Emil Staiger, and Le sens de la mémoire, by JeanYves and Marc Tadié, as a way to highlight the work that is developed involving the five senses and the lyric feature of this production, based on the feeling of memory.
\end{abstract}

Keywords: Carlos Drummond de Andrade; Boitempo; memory.

Le souvenir d'une certaine image n'est que le regret d'un certain instant; et les maisons, les routes, les avenues sont fugitives, hélas, comme les années (Marcel Proust, Du côté de chez Swann).

Para iniciarmos uma análise sobre a obra de Carlos Drummond de Andrade, podemos afirmar que a figura paterna ou a cidade natal são presenças constantes na produção lírica do poeta, inclusive em obras como Sentimento do mundo ou A rosa do povo, marcadas pela contundente crítica social. Mas é somente com a maturidade que o poeta mineiro recupera os elementos de sua vivência pessoal e utiliza-os como matéria por excelência do seu fazer poético. Nas três obras que receberam o nome de Boitempo, Drummond reune um conjunto de memórias e nos deixa como herança. O primeiro volume, Boitempo I-(In) Memória, foi publicado em 1968, seguido por Boitempo II - Menino antigo (1973) e por Boitempo III Esquecer para lembrar (1979).

\footnotetext{
" Juliana Santos é aluna do PPG-Letras da UFRGS. Entre seus trabalhos destaca-se: "Frase fonológica e choque de acento", com a co-autoria de Gisela Collischonn, nos Anais do $5^{\circ}$ Encontro do CelSul - Círculo de Estudos Lingüísticos do Sul, Curitiba, 2003.
} 
Ao organizar a coletânea de suas poesias para a Nova Aguilar, Drummond agrupou esses três volumes sob o título Boitempo e dividiu a obra em nove partes, com os seguintes títulos: "Pretérito-mais-que-perfeito"; "Fazenda dos 12 Vintens, ou do Pontal, e terras em redor"; "Morar nesta casa"; "Notícias de clã"; "O menino e os grandes"; "Repertório urbano"; "Primeiro colégio"; "Fria Friburgo" e "Mocidade solta". Os poemas, como os títulos já indicam, tratam das lembranças de sua infância; da fazenda; dos amores e descobertas da adolescência; do difícil período escolar; dos objetos, histórias e pessoas que marcaram a sua vida passada.

A partir desse conjunto, é interessante destacar a existência de um número bastante expressivo de poemas que se referem a memórias da primeira infância e que são marcados pelo lirismo e pela musicalidade. Segundo Jean-Yves e Marc Tadié (1999, p. 300), "la forte charge affective de ces souvenirs d'enfance montre que celle-ci est vraiment la période où nous sommes le plus réceptifs, le plus sensibles, le plus vulnérables"

O poema a seguir faz parte das composições líricas que tratam das mémórias de infância do poeta:

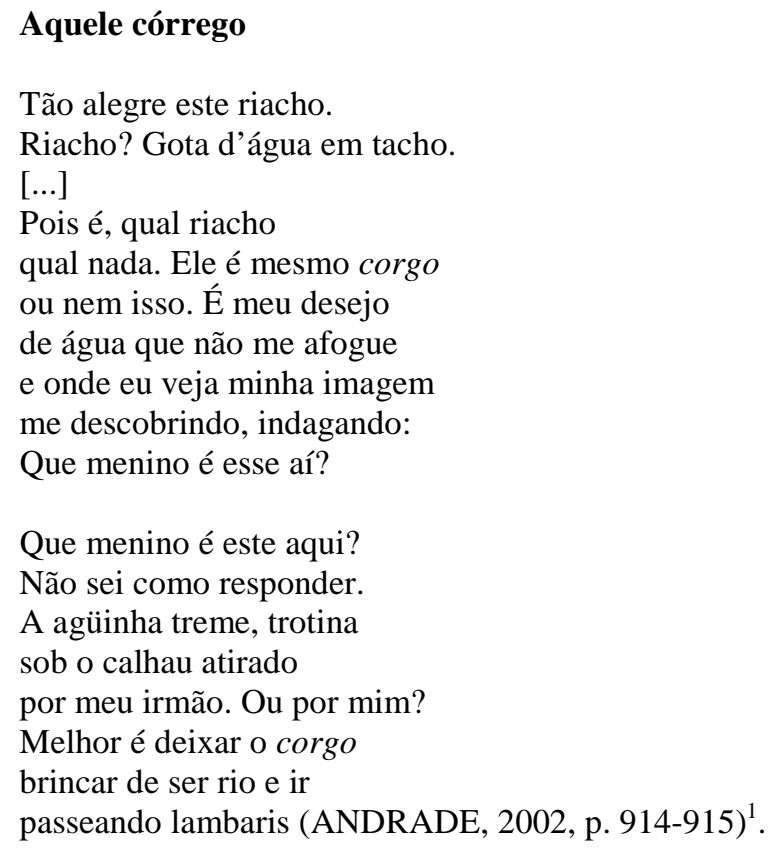

Nele percebemos o menino que procura descobrir a própria identidade e o homem que, ao recuperar pela memória este momento, percebe a imprecisão de suas lembranças ("Ou por mim?”). Conforme Tadié (1999, p. 213), que destaca esse caráter fragmentário, impreciso do ato de relembrar, “tout souvenir est entaché d'imprécision, d'effacement, de lacune, c'est-à-

\footnotetext{
${ }^{1}$ Todas as citações da obra de Drummond foram retiradas da obra ANDRADE, Carlos Drummond de. Poesia completa - conforme as disposições do autor. Rio de Janeiro: Nova Aguilar, 2002. A partir daqui serão indicadas apenas as páginas.
} 
dire de formes d'oubli” Drummond, por sua vez, também põe essa característica em destaque nos versos do poema “(In) Memória” - uma espécie de poema-programa da obra Boitempo -, já que o poeta o coloca ao lado de outras duas composições como uma espécie de abertura para os nove capítulos mencionados anteriormente.

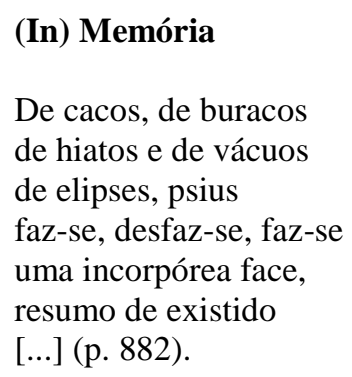

Ao tentar resgatar, reconstruir essa(s) incorpórea(s) face(s), Drummond aproxima-se, reencontra-se com os outros eus que ele foi e passa a re-sentir o mundo como naqueles tempos. Com isso, atreladas às suas lembranças, emergem as percepções sensíveis, corporais que experimentara em cada ocasião. Poder-se-ia afirmar ainda que os episódios ficaram guardados na memória em razão da impressão sensorial que os acompanhou.

Pour conserver [les souvenirs], il faut avoir perçu: notre corps est notre organe de perception, incontournable intermédiaire entre le monde extérieur et notre mémoire; c'est lui qui va recueillir par le biais des cinq sens: vision, audition, olfaction, goût et toucher, la matière première de nos souvenirs (TADIÉ, 1999, p. 103).

Um número considerável de poemas em Boitempo incorpora a percepção sensorial à lembrança que está sendo apresentada. Primeiramente, destacamos a experiência tátil presente nas composições. É notório que, quando aparece esse tipo de percepção, ela está vinculada ao aspecto da dor. Vejamos abaixo os fragmentos do poema "Surpresa":

\section{Surpresa}

\section{$[\ldots]$}

Meu cavalo me sabe seu irmão, seu rei e seu menino.

Por que, no vão estreito

(por baixo de seu pescoço eis que eu passava)

os duros dentes crava

em minhas costas, grava este protesto?

\section{Coro fazendeiro:}

O cavalo mordeu o menino?

Por acaso o menino ainda mama?

Vamos rir, vamos rir do cretino,

e se chora, que chore na cama (p. 909).

Nesses versos, podemos perceber o entrelaçamento que se estabelece entre a dor física, provocada pela mordida do cavalo, e a dor psíquica da humilhação causada pela fala dos mais velhos. Esta última parece ser a dor que mais fere o menino. A última frase proferida, "e se 
chora, que chore na cama", nos remete à expressão popular que diz "Pois que vá dormir na cama, que é lugar quente", o que fortalece a sua condição de inferioridade diante de uma voz que é coletiva. Ainda um outro poema se destaca ao trazer à tona uma lembrança envolta no sentimento da dor. Vejamos:

\title{
O beijo
}

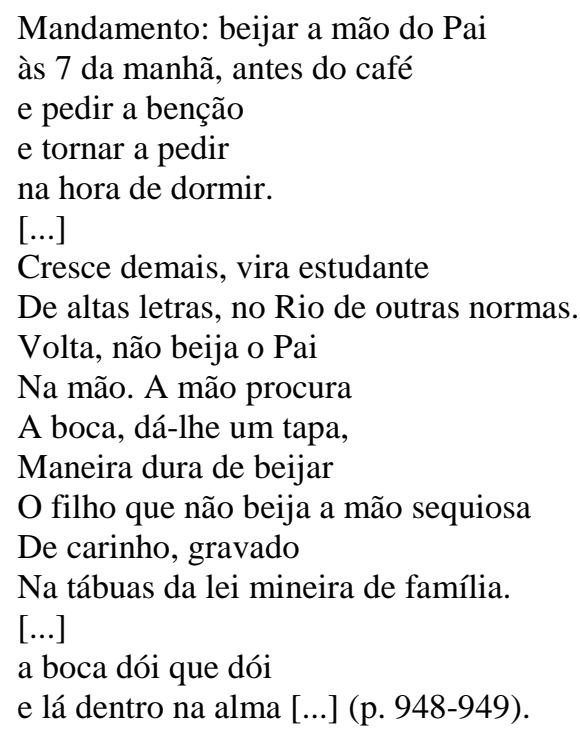

Nesses versos, vislumbramos a recorrente imagem da severidade do pai e dos costumes conservadores de Minas, recuperados a partir da rememoração do tapa, que haveria de ficar gravado para sempre em sua memória. Tadié (1999, p. 26) afirma que "un choc qualitatif peut compter davantage que la quantité des répétitions" para que uma vivência seja fixada na memória.

A exploração de imagens e da visualidade em seus poemas é motivo de destaque na obra de Drummond. Affonso Romano de Sant'Anna, ao referir-se à produção poética que vai de Claro enigma a Boitempo, chegou a afirmar que "entre o sentidos, a visão parece ser o mais empregado nessa poesia, e funciona como sinônimo de consciência" (1972, p. 206). Poderemos observar, no decorrer deste artigo, inúmeros poemas construídos a partir de um trabalho cuidadoso com a dinâmica e a composição das imagens. Destacaremos por ora o poema "Bota" para fazermos a análise:

\section{Bota}

\author{
A bota enorme \\ rendilhada de lama, esterco e carrapicho \\ regressa do dia penoso no curral, \\ no pasto, no capoeirão. \\ A bota agiganta \\ seu portador cansado mas olímpico. \\ Privilégio de filho \\ e ser chamado a fazer força \\ para descalçá-la, e a força é tanta
}


que caio de costas com a bota nas mãos e rio, rio de me ver enlameado (p. 906).

A imagem da enorme bota enlameada do pai - vista pelo filho ao descalçá-la - oferece ao leitor a possibilidade de ver a relação entre pai e filho, a partir da perspectiva com que o filho percebe o próprio pai. A imagem do menino, pequeno e aos pés de seu pai, nos dá a dimensão da força e do magnetismo que a figura paterna exerce sobre a criança. Aqui, mais próxima da figura do pai-herói.

Além disso, outro elemento se destaca: a apresentação de uma situação em que o "eunarrador" ${ }^{2}$ presentifica a sua lembrança e parece, ao final, reviver o momento enunciado - "e a força é tanta/ que caio de costas com a bota nas mãos/ e rio, rio de me ver enlameado.". Tal característica nos remete ao conceito de gênero lírico proposto por Emil Staiger. O teórico qualifica a lírica como terreno da recordação e aponta o presente como tempo gramatical por excelência do gênero. Nesse território, o passado não é tratado como objeto de narração, num simples movimento de memória, mas surge como desencadeador da experiência lírica, promove o re-sentir, o recordar. "O passado como tema do lírico é o tesouro da recordação". (cf. STAIGER, 1975, p. 54-55)

A ressonância sonora também faz parte dessa "memória em versos", , arquitetada por Drummond. O relógio da Matriz ou o sino Elias ficaram gravados na memória e, mais que isso, na pulsação do poeta. Vejamos o poema a seguir:

\title{
O relógio
}

Nenhum igual àquele.

\author{
A hora no bolso do colete é furtiva, \\ a hora na parede da sala é calma, \\ a hora na incidência da luz é silenciosa. \\ Mas a hora no relógio da Matriz é grave \\ como a consciência. \\ E repete. Repete. \\ Impossível dormir, se não a escuto. \\ Ficar acordado, sem sua batida. \\ Existir, se ela emudece. \\ Cada hora é fixada no ar, na alma, \\ continua sonhando na surdez. \\ Onde não há mais ninguém, ela chega e avisa
}

\footnotetext{
${ }^{2}$ Utilizo "eu-narrador" em detrimento de "eu-lírico" neste fragmento apenas com a intenção de chamar a atenção do leitor para o caráter narrativo desses versos de tendência autobiográfica. Raquel Rolando Souza apresentou, em 1997, a tese Boitempo: a poesia autobiográfica de Drummond, em que problematiza esta questão (Referência completa ao final). A tese já está publicada pela editora da Furg
}

${ }^{3}$ Expressão utilizada por Pedro Nava ao falar de Boitempo e referida por Davi Arrigucci Jr. (2002, p. 15-16) 
varando o pedregal da noite.

Som para ser ouvido no longilonge

do tempo da vida.

Imenso

no pulso

este relógio vai comigo (p. 1034).

Este som, ao se repetir, imprimiu o seu ritmo na consciência e na memória do poeta. Além disso, a cadência dos versos parece reproduzir a gravidade que provém do som produzido pelo relógio e, assim, o próprio leitor é tocado por esse ritmo. Tal composição nos remete novamente a Staiger e ao seu conceito de "disposição anímica". O teórico afirma que o poeta lírico, ao compor seus versos, "escuta sempre de novo em seu íntimo os acordes já uma vez entoados, recria-os, como os cria também no leitor" (1975, p. 28). Ele entende o momento da criação lírica como um "abandonar-se à inspiração", em que o poeta "inspira ao mesmo tempo clima e linguagem, sem dirigir-se nem a um nem a outro" (ibid., p. 28). No entanto, Staiger não desconsidera o cuidadoso planejamento por trás de uma obra que, aparentemente, foi fruto de uma construção involuntária. Afirma ainda o teórico:

A “disposição [anímica - Stimmung]" não é nada que exista "dentro" de nós; e sim, na disposição estamos maravilhosamente "fora", não diante das coisas mas nelas e elas em nós. A disposição apreende a realidade diretamente, melhor que qualquer intuição ou qualquer esforço de compreensão. [...] Todo ente em disposição é antes estado que objeto. Este ser estado é o modo de ser do homem e da natureza na poesia lírica (ibid., p. 59).

No poema a seguir, Drummond justapõe diferentes sons que fizeram parte de sua vivência na casa paterna para, ao fim, destacar o próprio silêncio enquanto som a ser perseguido e rememorado:

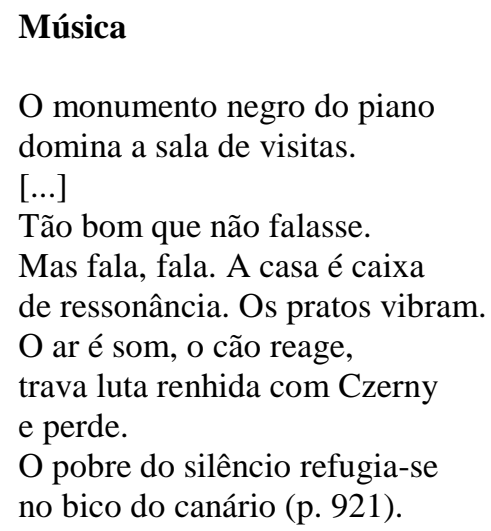

A música que provém do piano, o som dos pratos vibrando e o ladrar do cão impedem que o silêncio do campo e o canto do canário se expressem. Podemos perceber nesses versos uma sutil crítica ao mundo civilizado, que impede que o silêncio, a música natural do campo se estabeleçam. 
Muito recorrentes nessa obra de memórias, os sabores evocam as alegrias, o prazer simples e genuíno da infância vivida em Itabira. Lembra-nos Tadié que "la mémoire gustative, plus archaïque, a surtout été évoquée par Proust” (1999, p. 192) ${ }^{4}$. No entanto, em Proust, como no memorável episódio das madeleines, o sabor desperta involuntariamente memórias um tanto apagadas pelos anos e que serão aos poucos recuperadas. Já em Drummond, não há construções poéticas em que um passado fragmentário é refeito a partir da evocação de reminiscências despertadas pelo paladar ou quaisquer outros canais de experiência sensível. Em sua poesia, as lembranças, sensações parecem ser revividas como se estivessem sendo degustadas no exato instante em que são mencionadas. Vejamos algumas amostras dessa memória gustativa liricizada pelo poeta mineiro:

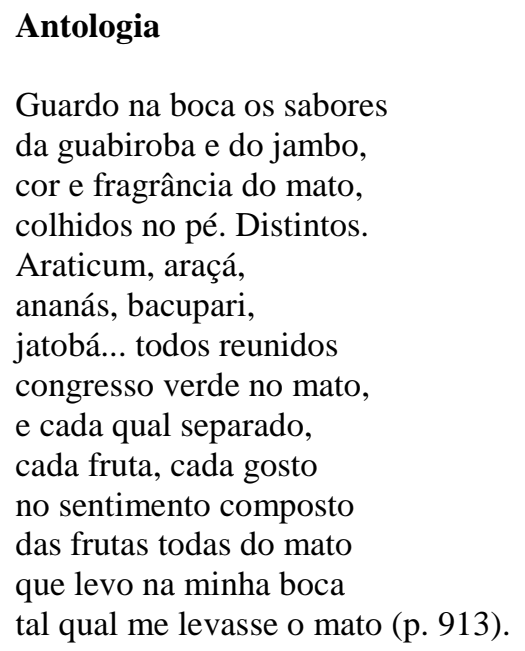

Podemos perceber, nesses versos, uma espécie de nostalgia, já que o prazer das frutas silvestres só pode ser experimentado nesse momento pela memória, mas não concretamente. Destacamos ainda a junção entre gosto, "cor e fragrância do mato" elaborada pelo poeta e que será exposta e melhor caracterizada no decorrer do ensaio. Vejamos ainda mais um poema que focaliza a memória gustativa:

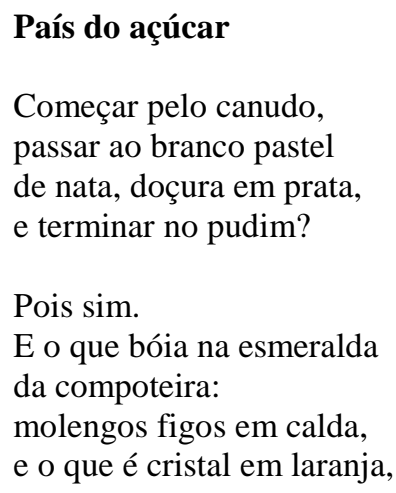

\footnotetext{
${ }^{4}$ José Guilherme Merquior (1978, p. 131) chega a aproximar a poesia de Boitempo da obra proustiana ao afirmar que "Drummond parece ter chegado a uma pausa em Boitempo: a pausa em que a dor do perdido e do espinho do desejo cede ao prazer imperturbado da degustação das madeleines itabiranas, em sábio sossego rememorativo".
} 
pêssego, cidra - vidrados?

A gula, faz tanto tempo, cristalizada (p. 927-928).

Nos versos acima, temos claramente diante de nossos olhos um menino em plena farra gastronômica, que logo nos remete à experiência de João e Maria ao chegarem na casa de doces. A musicalidade do poema também nos encaminha para uma vivência infantil. No entanto, os dois últimos versos trazem à tona a voz do adulto, distanciado da situação enunciada anteriormente. Adiante voltaremos a esta questão da perspectiva do eu-lírico em relação a suas memórias.

O próximo poema também se desenvolve a partir de uma referência ao paladar (e mesmo ao olfato) com o intuito de marcar sua origem. Dessa vez, como meio de impor a sua identidade mineira e itabirana:

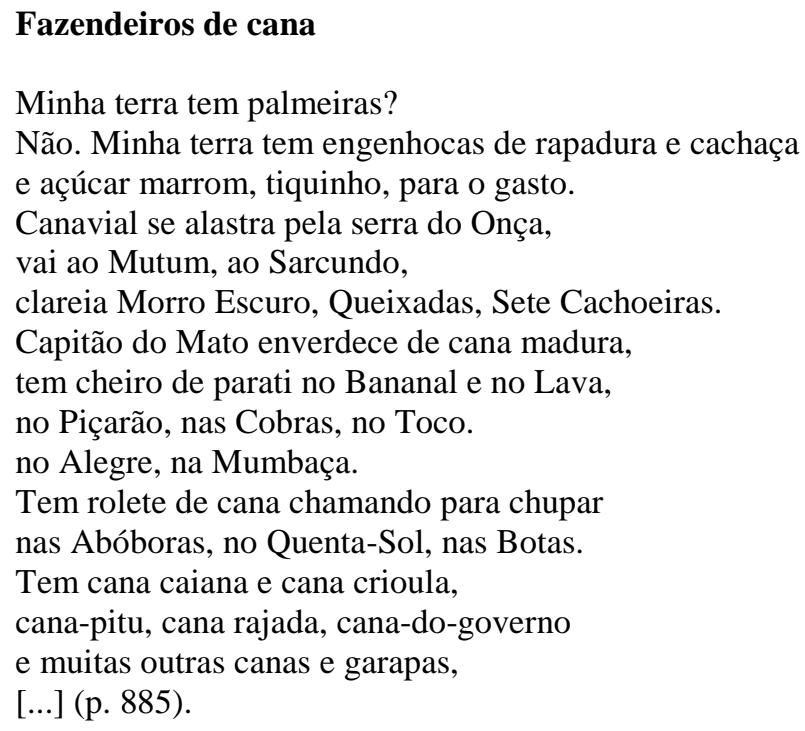

Drummond se utiliza dos versos clássicos de Gonçalves Dias (e da imagem de Brasil um tanto estereotipada que veiculam) para reforçar sua identidade e origem. Além disso, o poema também apresenta um mapeamento bastante minucioso da região a que pertence(u) e da variedade de canas que tal região produz. O poeta parece querer, por intermédio da criação poética, imortalizar esses locais e produtos que tão bem conheceu no passado e que, com a passagem dos anos, podem vir a desaparecer. Tal procedimento fica mais evidente ao nos depararmos com inúmeros outros poemas com esse caráter descritivo e/ou enumerativo.

Em menor número, encontramos referências à memória olfativa. No poema anterior o "cheiro de parati" é mencionado. Abaixo, temos fragmentos da composição em louvor ao capim-gordura, em que o aroma vai dar início à celebração dos benefícios da planta. Vejamos:

\section{Melinis minutiflora}




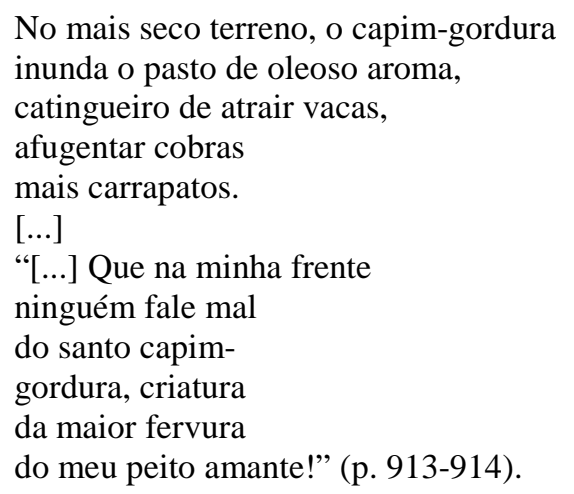

Além do perfume, outras percepções de campos sensíveis distintos são recuperadas para sugerir o ambiente tranqüilo e mesmo lírico da vida na fazenda. Vejamos:

\title{
Copo d'água no sereno
}

\author{
O copo no peitoril \\ Convoca os eflúvios da noite. \\ Vem o frio nevoso \\ Da serra. \\ Vêm os perfumes brandos \\ Do mato dormindo. \\ Vem o gosto delicado \\ Da brisa. \\ E pousam na água (p. 931).
}

O poema permite estabelecermos um sutil entrelaçamento, uma possível identidade entre o copo d'água e o próprio sujeito-lírico. É este quem “convoca os eflúvios da noite" e sente pousar sobre si a realidade imaterial percebida e construída por intermédio dos sentidos. O eu-lírico torna-se copo no peitoril a experimentar novamente o "frio nevoso da serra", o perfume do mato e o gosto de brisa de um passado distante. Nesses versos, o que era objeto torna-se sujeito a partir do momento em que é incorporado pelo eu-lírico. ${ }^{5}$

Em “Copo d'água” (assim como em “Antologia”, mencionado anteriormente), mais de um meio de percepção é ativado para compor a vivência evocada. Em Boitempo, encontramos ainda outras composições líricas que contém uma fusão de sentidos como forma de expressão. Abaixo temos alguns fragmentos do poema intitulado "O licoreiro":

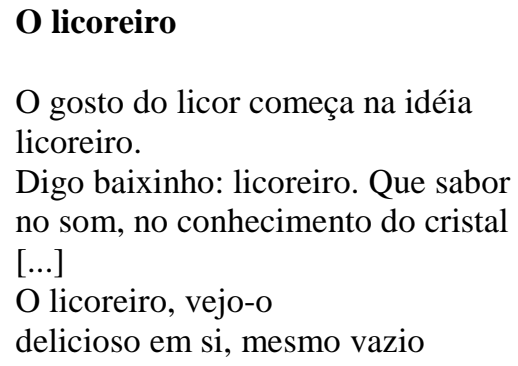

\footnotetext{
${ }^{5}$ Aproprio-me aqui das palavras de Paul Valéry: «Ce qui fut objet devient sujet car nous nous l'incorporons.» (apud TADIÉ, 1999, p. 136)
} 
à espera de licor, de tal maneira

na forma trabalhada

habita o gosto perfumado

e em cada prisma-luz se distribui

ao paladar da vista já gozando.

- Que tem esse menino, a contemplar

o tempo todo o licoreiro

se dentro dele não há nada?

[...] (p. 925).

Podemos observar em tais fragmentros que imagem, sabor e perfume se combinam e completam ao tornar vivo, por meio da lembrança, o apreciado objeto da vida passada. Tadié (1999, p. 137) afirma que "un souvenir ne sera que rarement visuel uniquement, ou olfactif, ou auditif; il sera bien souvent au centre de ces sensations: quand j'évoque un souvenir de mer em Bretagne, je la vois, je la sens et je l'entends à la fois".

Temos ainda mais um exemplo dessa junção de sentidos ao recuperar uma emoção pretérita:

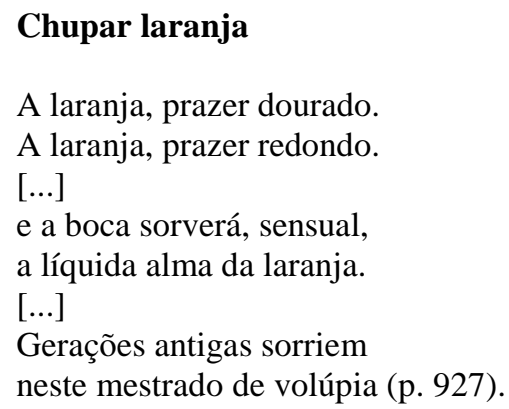

Nesses versos, as experiências visual, tátil e gustativa são presentificadas para compor uma cena repleta de sensualidade, gerada a partir de uma atividade cotidiana. $\mathrm{O}$ ato estabelece um elo, aproxima-o de seus ancestrais e da própria humanidade como um todo.

Os poemas que analisamos até o momento trazem à tona as experiências dos sentidos, à medida que estão vinculadas às memórias que o eu-lírico recupera. Por vezes, a vivência sensorial está intimamente relacionada à rememoração de acontecimentos marcantes do passado. Mas "non seulement les événements, mais les individus peuvent ainsi s'imprimer dans la mémoire" (TADIÉ, 1999, p. 116). Drummond também retira de seu baú de recordações diversas pessoas, lugares, marcas culturais que fizeram e fazem parte da história do homem que hoje ele é.

Ao relembrar todo esse universo, o poeta parece querer fixá-lo, torná-lo patrimônio não apenas pessoal mas também coletivo. Seus versos imortalizam as mulheres que representaram a força, a proteção e o amor aos homens do clã ("Litania das mulheres do passado", p. 894), os vários Carlos com quem se deparou e que o puseram frente-a-frente de si 
mesmo ("Etiqueta", p. 979), a forte e constante presença de Sá Maria ("Cantiguinha”, p. 955; “O preparado", p. 956; “Anjo-guerreiro", p. 956-957) entre muitos outros.

Os ambientes e os locais do passado também são motivos poéticos para essa obra de memórias. No poema "Fazendeiros de cana", pudemos ter acesso ao universo dos canaviais com o qual conviveu o poeta. Em outras composições, podemos nos aproximar de sua cidade, fazer um passeio de bonde e de dentro dele avistar os lugares que um dia conheceu ("Hino ao bonde", p. 1135-1137), percorrer as ruas da cidade (“A rua em mim”, p. 1045), penetrar no universo de lugares amados como a "Livraria Alves" (p. 1096) ou o cinema Odeon ("O fim das coisas", p. 1144-1145).

Nesse último poema, mais do que recordação individual, temos claramente o registro (e uma certa crítica) das mudanças culturais pelas quais passava (e ainda passa) o Brasil:

\section{O fim das coisas}

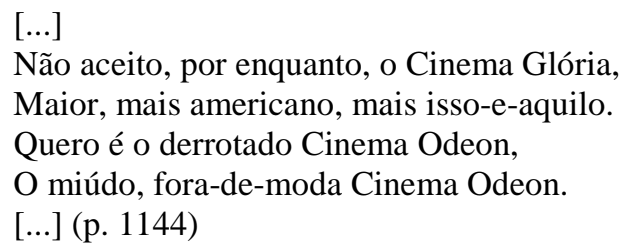

Nesses versos, assim como em vários outros em meio a tecedura das recordações, temos uma nítida sensação de que este é um conjunto de memórias que vai além do plano íntimo para alcançar uma legitimidade de memória coletiva e histórica. Como afirma Jackson:

Une lecture est une construction, une écriture est une construction. Construction de quoi? Construction de soi-même, bien sûr, d'abord; construction de cet objet au statut si particulier qu'est um texte, ensuite; construction enfin d'une profondeur mémorielle à la fois littéraire, culturelle et même historique (1992, p. 94).

Tal afirmativa alia-se perfeitamente à célebre conferência sobre "Lírica e sociedade", proferida por Theodor Adorno (1980):

em todo poema lírico a relação histórica do sujeito à objetividade, do indivíduo à sociedade, precisa ter encontrado a sua materialização no elemento do espírito subjetivo, reverberado sobre si mesmo. Essa sedimentação será tanto mais perfeita quanto menos a formação lírica tematizar a relação entre eu e sociedade, quanto mais involuntariamente cristalizar-se essa relação, a partir de si mesma, no poema (ADORNO, 1980, p. 197).

Ao adentrarmos nesse universo de recordações, podemos participar um pouco dessa realidade histórica que nos pertence, mesmo que não vivenciada de forma plena. Ali podemos escutar as vozes que vêm do povo e seu humor próprio ("Os excêntricos", p. 890-891; "Enigma", p. 1108-1109), as brincadeiras e jogos da infância, "lusamente brasileiras,/ ou melhor, universais” (“A separação das casas”, p. 1067-1069) e ainda vivenciar as músicas 
("Verso proibido", p. 1107), filmes (“A difícil escolha”, p. 1140 e "O grande filme”, p. 11401141) e jornais (“Imprensa”, p. 1043-1044) que marcaram uma época.

Tratemos agora das estruturas que Drummond utilizou para apresentar seu conjunto de memórias. Destacamos dois tipos de construção, por aparecerem em maior quantidade no decorrer da obra em questão. Anteriormente, ao analisarmos o poema "País do açúcar", pudemos observar um dos tipos de perspectiva em que se coloca o eu-lírico ao explorar seu universo de memórias. Há nessa construção um corte entre o eu que vive a experiência e o eu que revive tal experiência por intermédio da memória. O menino, após ter se deliciado com todas as guloseimas da infância, dá voz ao homem que, por sua vez, acabava também de saboreá-las - "a gula, faz tanto tempo,/ cristalizada". O leitor tem diante de si, num mesmo poema, o menino presentificado, vivendo as experiências de um passado-presente, e o homem, consciente da distância que o separa desse outro eu. Há, em Boitempo, muitas construções poéticas seguindo tal modelo, caracterizado pela ruptura e pela cisão do sujeito lírico no interior de um mesmo poema.

Também em grande quantidade, encontramos composições em que cada uma das "personagens", cada um desses outros eus presos a uma existência pretérita assume uma unidade e uma voz autônoma no interior de uma criação lírica. Num dos três poemas que introduzem a obra analisada, temos a indicação desse procedimento de presentificar os momentos vividos, dando voz a esses inúmeros eus que constituiram a sua vida pregressa. Observemos o "poema-programa" intitulado "Intimação":

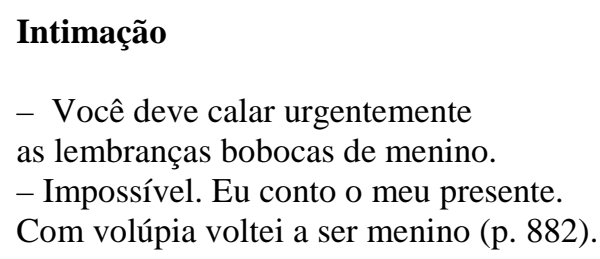

Como amostra desse procedimento de dar vida e voz a um eu pretérito, presentificando-o, elegemos o poema a seguir:

\section{Banho de bacia}

No meio do quarto a piscina móvel tem o tamanho do corpo sentado. Água tá pelando! mas quem ouve o grito deste menino condenado ao banho? Grite à vontade.

Se não toma banho não vai passear.

E quem toma banho em calda de inferno?

Mentira dele, água tá morninha,

só meia chaleira, o resto é da bica.

Arrisco um pé, outro pé depois. 
Vapor vaporeja no quarto fechado ou no meu protesto.

A água se abre à faca do corpo

e pula, se entorna em ondas domésticas.

Em posição de Buda me ensabôo, resignado me contemplo.

O mundo é estreito. Uma prisão de água envolve o ser, uma prisão redonda.

Então me faço prisioneiro livre.

Livre de estar preso. Que ninguém me solte

deste círculo de água, na distância

de tudo mais. $\mathrm{O}$ quarto. $\mathrm{O}$ banho. $\mathrm{O}$ só.

$\mathrm{O}$ morno. $\mathrm{O}$ ensaboado. $\mathrm{O}$ toda-vida.

Podem reclamar,

podem arrombar

a porta. Não me entrego

ao dia e seu dever (p. 938).

É quase impossível que o leitor não compartilhe com o menino o prazer pelo contato com a água. Os versos convidam a que nós também nos entreguemos a esse delicioso momento do banho, do só, do morno, do ensaboado, rompendo com as barreiras do tempo. A qualidade lírica, a delicadeza das imagens colocam-nos em estado semelhante ao do menino. "Le poème le plus incarné, le plus chargé de réminiscences privées peut se découvrir une fonction exemplaire [...][il] prête à l'expérience privée, singulière, un statut de validité universel" (JACKSON, 1992, p. 180).

O último aspecto que gostaríamos de destacar é o papel que assume a musicalidade, mais precisamente a repetição, nesta obra que tem por matéria-prima a recordação. Para Staiger (1975, p. 23-24), "nem somente a música das palavras, nem somente a sua significação perfazem o milagre da lírica, mas sim ambos unidos em um".

Em outras obras do poeta mineiro, muitas vezes nos deparamos com versos em que o uso de rimas, repetições assumem uma conotação um tanto irônica, criando uma certa tensão no interior da composição. Em Boitempo, na maior parte dos casos, nos deparamos com poemas em que esses mesmos artifícios têm a finalidade de conferir maior densidade lírica à composição. Podemos observar esse procedimento no poema a seguir:

\section{Cantiguinha}

Era um brinquedo maria era uma estória maria era uma nuvem maria era uma graça maria era um bocado maria era um mar de amor maria era uma vez era um dia maria (p. 955). 
A figura de Sá Maria, representada também em outros poemas, surge nessa pequena composição lírica envolta num sentimento de ternura. A repetição aqui cumpre papel fundamental, pois confere maior delicadeza na expressão desse sentimento. Além disso, a estrutura simples e a própria escassez vocabular da fala infantil ressoam nessa pequena canção de "era uma vez".

No poema "Parêmia de cavalo", temos mais um exemplo em que rimas e repetições servem de instrumento para uma composição de feição lírica. No entanto, o lirismo aqui encontra-se no humor, na leveza da infância, construídos com o auxílio dessas ferramentas sonoras. Vejamos:

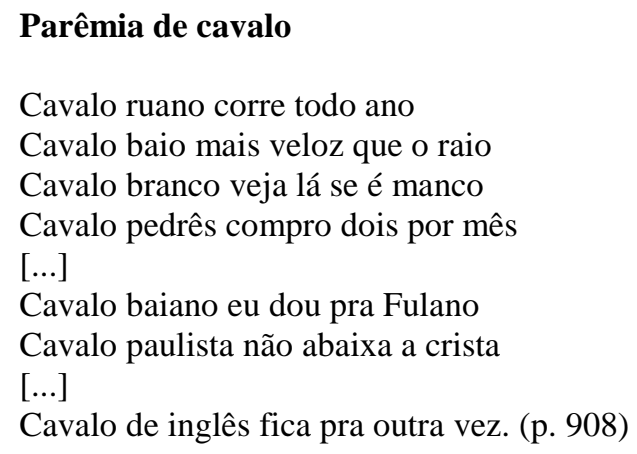

Nesses versos percebemos o menino a abandonar-se num divertido jogo de linguagem. A repetição assume aqui seu aspecto lúdico e permite que o sujeito, ao ingressar nessa cadência rítmica, seja encaminhado a uma nova realidade, a uma condição liberta da consciência do tempo exterior.

A repetição parece ser a arma que o poeta utiliza para vencer as barreiras do tempo e reviver ainda uma vez certas sensações de sua existência, voltando a ser, talvez uma última vez, o sujeito que um dia as sentiu.

Ao final do percurso, percebemos que, com Boitempo, Drummond imortalizou inúmeras recordações de sua existência, não só por tê-las tornado resistentes ao tempo, por intermédio da linguagam escrita, mas principalmente por ter dado a elas o caráter universal de que são revestidas. Com isso, a universalidade alcançada pelo poeta é fruto de um fazer pautado na re-invenção constante de tudo o que foi vivido, imaginado e percebido por ele.

\section{Referências}

ADORNO, Theodor W. Lírica e Sociedade. In: BENJAMIN, Walter; HORKHEIMER, Max; ADORNO, Theodor W.; HABERMAS, Jürgen. Textos Escolhidos. Tradução de José Lino Grünnewald [et al.]. São Paulo: Abril Cultural, 1980. p. 193-208. (Coleção Os Pensadores) 
ANDRADE, Carlos Drummond de. Poesia completa - conforme as disposições do autor. 1. ed. Rio de Janeiro: Nova Aguilar, 2002.

ARRIGUCCI JR., Davi. Coração partido - Uma análise da poesia reflexiva de Drummond. São Paulo: Cosac \& Naify, 2002.

JACKSON, John E. Mémoire et création poétique. Paris: Mercure de France, 1992.

MERQUIOR, José Guilherme. Notas em função de Boitempo (I). In: CARLOS DRUMMOND DE ANDRADE - coletânea organizada por Sônia Brayner. Nota preliminar de Afrânio Coutinho. 2. ed. Rio de Janeiro: Civilização brasileira, 1978. p. 123-145. (Coleção Fortuna Crítica, v. 1)

SANT'ANNA, Affonso Romano de. Drummond, o gauche no tempo. Rio de Janeiro: Lia/INL, 1972.

SOUZA, Raquel Rolando. Boitempo: a poesia autobiográfica de Drummond. 1997. 311p. Tese (Doutorado em Letras) - Universidade Federal do Rio Grande do Sul, Porto Alegre, 1997.

STAIGER, Emil. Conceitos fundamentais da poética. Tradução de Celeste Aída Galeão. Rio de Janeiro: Tempo Brasileiro, 1975.

TADIÉ, Jean-Yves ; TADIÉ, Marc. Le sens de la mémoire. Paris: Gallimard, 1999. 